\title{
The Librarian Looks at the Publisher
}

\author{
Dr. Hirsch is librarian and professor of \\ history at Bard College.
}

$\mathrm{T}$ HE RELATIONS between the publisher and the librarian as guardian of his readers' interests need constant re-emphasizing, even though it is evident that libraries are not the most important factor for the American book business. The following remarks, while not uncritical of the publishing trade, are meant to help bridge the gap between publisher and librarian. In making his comments, the author is fully aware of the difficult situation in which the American book trade finds itself today. So able an analyst as J. K. Lasser has recently ${ }^{2}$ spoken of publishing as "a large, but ailing business" and has claimed that those trade book publishers who are clients of his accounting firm, have annual total earnings of less than 3 per cent after taxes have been paid. Also another unbiased observer, William Miller, ${ }^{3}$ has taken a rather gloomy view of this industry and its prospects.

\section{Libraries as Customers}

Before looking at the publisher, a quick glance at the librarian may be in order. First of all, how significant are libraries actually as customers of the book trade? Ac-

\footnotetext{
1 Paper presented at the meeting of the ALA Book Acquisitions Committee, Cleveland, July I9, I950.

${ }^{2}$ Lasser, J. K. "The Book Business-With and without Profit." Saturday Review of Literature, $32: 9$, Oct. 29. 1949.

${ }^{3}$ Miller, William. The Book Industry (A Report of the Public Library Inquiry). New York, Columbia University Press, I950. Chapter V, "Trade Publishing and the Public Libraries," is especially relevant. See also the spirited criticism of Miller's book which John Farrar presented under the title "Publishing: Industry and Profession." American Scholar, I9:9, Winter 1949-50; and the excellent earlier treatment of the whole subject by Frederic G. Melcher in The Practice of Book Selection, ed. by L. R. Wilson. Chicago, University of Chicago Press, 1940, p. 272.87.
}

cording to William Miller, ${ }^{4}$ all American libraries spent in 1948 about $\$ 32,000,000$ for books and periodicals. Public libraries alone absorbed $\$ 8,400$, ooo worth or nine per cent of the trade publishing. College and university libraries may have a more limited clientele, but are also important customers. According to the latest statistics, ${ }^{5}$ some outstanding large institutions like Harvard and Yale, but also some small ones, such as Wells and Bard, spend annually about $\$ 30.00$ or more per capita for books, periodicals and binding. These are impressive figures, but librarians, and especially academic librarians, should endeavor to raise their sights still more. They should have no inhibitions when it comes to lobbying for better book budgets, for the last $\$$ Iooo really decides whether a librarian can buy only the "must" books or also those which would help to improve the level of the collection.

Secondly, librarians should ask themselves whether or not they always select books which combine timeliness with enduring value. In choosing new titles, do they merely follow the trends of best sellerdom or are they striving to uphold the best standards? If librarians just try to meet the average demands for the popular bookgood, bad or indifferent-they will be of little help to that publisher who aims to present unusual titles of high merit. William Miller's contention "that most libraries (i.e. public libraries) do not and, indeed, cannot buy many serious titles and

4 Ibid., p. $12 \mathrm{I}$. I 950 .

"College and Rescarch Libraries, I I:151-63, April 
that those that buy a few cannot buy many copies of them," 6 if correct, would be a grave reflection on the situation of presentday libraries.

Thirdly, and above all, do librarians work hard enough to convince their clientele that there is no greater joy than to build up a collection of one's own? This writer concurs with the Swiss librarian Marcel Godet who said: "It cannot be doubted that the book one has bought and owns, has, intellectually speaking, greater value than the book one borrows." " Therefore, it is one of the librarian's noblest functions to promote the development of private collections, be they small or large. No librarian active along these lines need fear that he is endangering the business of his library thereby. Bernard Berelson has just presented statistical evidence that "the larger the home collection, the more use is made of the public library." 8 Librarians working in educational institutions often make the same observation. The students whom they help informally in getting started on a collection of their own do not cease to be good library customers for that reason. There are many effective ways of promoting this worthy cause..$^{9}$ In a small institution like Bard the library staff can do this job in friendly conversations; in larger places more elaborate methods of encouragement are desirable. Some college libraries award cash prizes to the students whose private collections are outstanding in a campus-wide contest. In Rockford College the librarian arranges a "reprint tea" in the early fall. She says: "It must be admitted

Miller, op. cit., p. I 24 :

7 Godet, Marcel. Bibliotheques Americaines. Berne, I935, p. 2 I, as quoted in Munthe, William. American Librarianship from a European Angle. Chicago, r939. Munthe offers in his second chapter some very pertinent comments on books and reading in America and in Europe.

${ }_{8}$ Berelson, Bernard. The Library Public (A Report of the Public Library Inquiry). New York, Columbia

University Press, I949, p. 16 . ${ }^{9}$ Lyle, Guy R. The Administration of the College 'Lyle, Guy R. The Administration of the College
Library. 2d ed. New York, Wilson, 1949, p. 239-41. that the lure of tea and cookies often brings a bigger crowd than would a library talk alone, but frequently those who come to enjoy the tea, are known to leave with an interest in the what and where of bookbuying." 10 In a way librarians shoulder here, as an honorary task, what is in Europe the regular function of the bookseller, and I wish that American bookstores would see in them only their unselfish friends, not their competitors.

\section{What Kind of Reprints?}

The topic of reprints leads directly to the first suggestion which is offered here to American publishers. They are at present thinking of new ways to widen their markets, for it is evident that some of them may not survive if their business does not expand considerably. This writer grew up in Germany where some publishers realized, long before the first World War, that young people of modest means could buy only inexpensive books, but that these should be so well manufactured that they could become part of a lifetime library. For the equivalent of a quarter, the Inselbuch was available with attractive hard covers; its contents were invariably of high literary or artistic merit. Often an Inselbuch would consist only of art reproductions, woodcuts, etchings, and later on also of paintings in multicolors. How many of us received our first introduction to Dürer and Holbein from these wonderful little books! It is encouraging to see that Pocket Books are now experimenting with very well-done art volumes. It should be possible to sell such books by the hundreds of thousands to a generation that is so much more art-conscious than its forefathers were. Otherwise, the experiences with 25-cent books have not always been gratifying to librar-

10 Sharpe, Jean MacNeill. "Student Libraries." Wilson Library Bulletin, 23:70-71, September 1948. 
ians. For every good book available in such inexpensive editions there are too many that are plain tripe, while Inselbücherei, Reclam's Universal-Bibliothek and similar collections avoided concessions to vulgar tastes.

\section{Good Books for a Dollar!}

The second series with which this writer grew up and whose slender volumes, bound solidly in light brown cloth, he still treasures after 30 years or more, is the Sammlung Göschen. It consists of about 1000 volumes, priced at the equivalent of $60 \%$ or 70\%, covering almost all fields of knowledge and written by experts, but as a rule in nontechnical language. There can be little doubt that we have an enormous potential market for books of this kind in the U.S.A. The English have developed similar largescale enterprises which serve the purposes of adult education and help to introduce students elegantly to important subjects. The Home University Library, which contains some first-rate volumes contributed by world-renowned British scholars, is one of these series. More recently the Teach Yourself History Library, ably edited by A. L. Rowse, has made its appearance; its volumes are excellent for the beginner, whether adult or of college age. This series is published in England, according to the Cumulative Book Index, at 5s, i.e. 7o per volume, but sells in this country at $\$ 2.00$ (though actually printed in Great Britain). Would not a wise publisher, anxious to approach a wider market, pass on such currency difference to his customers? This splendid series certainly would enjoy much wider sales if the price were down to $\$$ I.Oo.

In the reprint field some series have been very effective along these lines, although at times the selection might benefit from a more catholic taste. The new American edition of Everyman's Library looks perhaps most appealing from the point of view of the private reader. Binding, printing and paper seem attractive; to own St. Augustine's Confessions or Hobbes' Leviathan in this edition is nothing to be ashamed of. This American edition of Everyman's suits also the needs of libraries for additional copies of great books. This collection is eventually to grow to 250 titles. It is too early to compare its standards of selection with those of the Modern Library, whose binding and paper have not always been pleasing. Many instructors and librarians have great expectations for the new college edition of the Modern Library. Another excellent series, the Viking Portable Library, unfortunately has just gone up in price. This may affect its popularity among the less well-to-do. William Miller, by the way, offers a number of suggestions in the reprint field which might be applied also by college and university librarians. For instance, he mentions the possibility that a large number of libraries or the ALA might "rent plates from publishers at the same low rates given commercial clubs, then produce their own books and distribute them almost at cost to member libraries."11 $\mathrm{He}$ also thinks of groups of libraries or the ALA guaranteeing to publishers a considerable minimum of sales for new books with uncertain market appeal and, finally, of purchasing reprint rights to books in great demand at libraries and issuing them in pocket-size paper-bound editions.

\section{Inexpensive Art Books}

American publishing has not yet caught up with Europe in still another area, that of art books. There is potentially an enormous demand for good medium-priced art books in this country. The fact that hundreds of thousands went to see the exhibitions of the German and Austrian master-

11 Miller, op. cit., p. I 29. 
pieces, to the Van Gogh show and many similar events, demonstrates beyond a reasonable doubt that the hunger for good art is ever growing in the USA. But our publishers, with a few laudable exceptions, have not yet mastered the technique of bringing out art books that could compare in quality and price, e.g., with the output of the Phaidon Press in London. This affiliate of the Oxford University Press issues volumes containing many first-rate reproductions in giant size, at $\$ 5.00$, and pocket editions of some great works of art history at \$2.50. It is true that labor and materials are more costly in this country than in England, France (with her Hyperion Press), or Germany, but America surpasses all of them in production methods. If we can bring out on the assembly line millions of comparatively inexpensive cars, refrigerators and television sets, why not also reasonably priced art books? It is a record of failure on the part of publishers and printers that only relatively few worth-while American art publications sell at less than $\$ 8.00$ or $\$ 10.00$; therefore, many of these art books never reach the people who would appreciate them most.

Another market with great potentialities has not yet been opened up either. Every public librarian knows that there are many millions of adults whose education has been so limited that the books available on library shelves are far above their level of reading comprehension. These people don't want to read children's books. They are mature citizens, merely underprivileged in their education and thus handicapped in their reading abilities. If public libraries had enough books especially designed to meet their needs, they might become their loyal customers instead of bypassing the library buildings, but the publishing trade has not yet seized this opportunity. College li- brarians and instructors are also familiar with freshmen who have reading difficulties. As this writer has frequently observed, not all these students are poor risks. Among them are some who will make the grade if they receive proper guidance and if there are enough rather simply-written books around from which to get started.

\section{"Immediate Important Sales"}

Could book prices come down in general? The publishers believe they cannot cut the prices; on the contrary, they will insist that they have been too cautious in raising them since the end of World War II. Perhaps they are correct in their protestations, as long as certain pernicious tendencies in the book business cannot be arrested. The fact must be faced that many, if not most, trade books in America are dead after one season. Everybody shares in the responsibility for this deplorable situation. The public is fickle in its tastes and follows fashions or fads to a considerable extent in its book purchases. A work like $W$ orlds in Collision has enormous sales, although experts were highly critical of it from the beginning, and at present we observe with dismay the equally amazing boom of Dianetics. Librarians do not always aim at the proper standards either, although the previews in the Library Journal, written by their own colleagues, and various other noncommercial reviewing tools could save them from many a misspent dollar. The publishers finally, knowing the market situation with all the risks of costly storage and excessive capital investments, aim too much at "immediate important sales," as one of them put it to this writer sometime ago.

All of us should work together to find ways in which the life of those books would be prolonged that have been worth publishing. If his memory does not betray this 
writer, books in Europe, generally speaking, had a much longer life in his time over there. This would save librarians, for instance, from many of the headaches they have today with out-of-print books. A noted English expert, L. Stanley Jast, former head of the Manchester Public Library, has said so aptly: "The burial of a living person is a horror. The burial of a living book is a tragedy, made the deeper by the many births of dead ones." 12 Publishers probably would raise their standards of selection and concern themselves less with the sale of their rights to book clubs, to the movies, to periodicals for serialization, and to reprint houses, if the normal good book would have a longer life expectancy and if they could rely on more revenue from their backlist. Maybe librarians should help them, as William Miller proposes, ${ }^{13}$ by guaranteeing a considerable minimum of sales for older items (needed for replacements) which would otherwise be allowed to go out of print.

\section{Vital Books from Abroad}

There could be quite a saving on overediting. Let the responsibility for the proper presentation of a book rest squarely with the author! Don't pad, don't rewrite his books! Let the editor gain more time for talent scouting, especially for canvassing the whole range of good foreign books! American publishers, excepting Knopf, Viking, Norton, a few others, and some university presses, have not made enough effort to bring the most significant books from abroad in adequate translations to the attention of the American public. A few examples, chosen at random, may suffice to prove this point. When the Swiss novelist Hermann Hesse received the Nobel Prize in

\footnotetext{
12 Jast, L. S. "Libraries and Publishers." Library Association Record, $4 \mathrm{I}: 8$, January $\mathrm{I} 939$.

13 Miller, op. cit., p. I 29.
}

Literature, even the learned editor of the New York Times expressed surprise about the choice: "The literary award ... creates an international fame where none existed before."14 This writer took the liberty to correct the editor in a letter which was printed at once, stating that it was a reflection on the American publishing business, if Hesse was little known in this country; only a few books from his large oeuvre had been translated, whereas in Europe all his works were sold by the tens or hundreds of thousands. Is it not ridiculous that most of Max Weber's sociological writings were made accessible to American students only a generation after his death? Also that the one monumental Bismarck biography written in our time, that by Erich Eyck (published in Switzerland during World War II), has been presented to the Anglo-Saxon world only now, in a terribly condensed version, while so many recent light-weight biographies from abroad appeared on the market immediately and unabridged ${ }^{15}$

As to world affairs, are our publishers really doing all that can be expected of them in an era when America has become a superpower and is shouldering such heavy responsibilities abroad? Again a characteristic example: Two, and only two, first-rate books were published in Germany shortly after the Third Reich collapsed; they revealed more about the German frame of mind than loads of "quickies" written by self-styled American experts on the subject. One was Friedrich Meinecke's German Catastrophe. It was published, at last, in January 1950 by the Harvard University Press, when it was already dated in spots. The other, Eugen Kogon's Theory and Practice of Hell (German title: Der S. S. Staat), was on the list of Farrar, Strauss

${ }^{14}$ New York Times, Nov, I6 and 20, 1946.

15 For further comments on this topic see Hirsch, Felix E. "Beyond All Frontiers." Current History", I 4:90-94, February 1948 . 
for Fall 1950, when Nazi concentration camps had lost some of their timely interest for the general reader. American publishing houses should be and could be much more alert in this respect.

Long is the list of sins of omission regarding Slavic civilization. Many of the great Russian authors have been available only in poor, if not abominable translations. Only recently have publishers begun to think of presenting Turgenev and some other past masters in the dignified form they deserve. It needed the Russian translation project of the American Council of Learned Societies to bring at least a taste of modern Russian scholarship to American readers. University presses, though well-intentioned, are not always too effective when it comes to widening the horizon of the American public. A fair critic, the historian Geoffrey Bruun, stated recently that "in a year when the history of other nations should attract millions of American readers, it is discouraging to find the offerings of the university presses in this field a matter for more regrets than congratulations."16 Again, here is a wide and constantly expanding market for enterprising, far-sighted publishers. Many hundreds, if not some thousands, of American libraries would buy up (possibly even guarantee to buy) every single good, solid, unsensational book on international affairs that publishers would have vision enough to bring out. How urgently are more sound and up-to-date books on southeast Asia needed, not to speak of Korea! Also at least one observer is convinced that in the production of world atlases we are still behind our ablest foreign competitors. Bartholomew's Advanced Atlas of Modern Geography, in its latest revision, costs in England only the equivalent of $\$ 4.00$; its maps of the non-American areas are vastly

16 Bruun, Geoffrey. "To the Sum of Knowledge." Saturday Revieze of Literature, 33:22, May 6, I950. superior to what is offered in more expensive atlases made in the USA.

\section{More Truthful Publicity!}

If more books are to be sold, we need more truthful publicity for them. Librarians have become hesitant when they see exaggerated praise of forthcoming books in publishers' advertisements or circulars. Those librarians who, for geographic reasons, cannot always examine the books themselves in good stores before the orders go out, feel especially annoyed by the ballyhoo of promotion campaigns by which they are misled. They dislike publishers' blurbs when they don't describe book and author accurately. The other day this writer perused with amusement a new book whose author was said to have been "long recognized as America's leading student of the economic, social and political problems of our industrial age." What an exaggeration! Would it not have been so much more honest and, for many people, more appetizing, if the blurb had just said that the author is a very able young economist?

Since we are on the subject of truth, it may seem permissible to ask American publishers to be more cautious when using the term "revised edition." Only too often the reader or librarian who has bought a revised edition on the strength of a publisher's advertisement finds out to his distress that actually just some minor flaws have been corrected; at best, a few pages have been appended in the last chapter to bring the text somehow up-to-date. It should be clearly understood whether a book has a new printing with some minor corrections or has been carefully revised throughout. Librarians are entitled to precise bibliographic information, and the recent recommendations of the ALA Book Acquisitions Committee to the American Book Publishers Council deserve emphatic endorsement. 


\section{Continuous Revision}

This writer takes even stronger exception to a related term, "continuous revision," as used by some highly-respectable encyclopedia makers. This term creates exaggerated expectations in the minds of individual readers, and also of many librarians. For instance, the Encyclopaedia Britannica claims to have revised or added 42,074 articles in the period 1932-1950. This sounds impressive. The reader who examines the 1950 printing of the Britannica, while admiring its enduring qualities, finds that much remains to be desired. Many topics of vital importance have not been properly revised and the bibliographies are in dire need of overhauling. The articles on some of the world's greatest dangerspots, such as Austria and Korea, are far from up-to-date. Franklin D. Roosevelt's biography devotes nine lines to his last nine years of office, and the article on him occupies only one third of the space allotted to Theodore Roosevelt-certainly a lack of historical proportion. These are but a few examples from a long list of desiderata. Walter Yust, the editor of the Britannica, states emphatically in a circular: "There will be no 15 th edition." Librarians can only reply: "The 15 th edition is needed."
Compliments are deserved by many American publishers for their efforts to improve book-making in the narrower sense of the word. A steady tendency toward more legible and more attractive printing may be detected, thanks to the educating influence of such pioneers as F. W. Goudy, Bruce Rogers, etc. The average American book of today has a more pleasing appearance than did the output of the printing presses a few decades ago. The efforts of publishers like Knopf, Random House, Viking and some others in this respect deserve the highest admiration. Even books of the university presses, many of which used to look rather dull, now measure up to high standards of design. That does not exclude occasional lapses, when unsolid binding, poor paper and narrow margins annoy the librarian. Also index-making and bibliographic information have improved.

In conclusion, it may be fairly said that as librarians we cannot always agree with the policies and practices of American publishers. We believe, however, that most of our grievances can be corrected and that the publishing business in the United States will be more prosperous and exert a more salutary influence, if it works hand in hand with its true friends, the librarians.

\section{College and University Library Statistics}

The ACRL Statistics Committee hopes to complete its work on the 1950-5 I statistics (with salary and certain budget information for the year 1951-52) by Nov. 15, 1951. The involved task of typesetting and proofreading these figures will be pushed as fast as possible and the material should appear in the January issue of College and Research Libraries instead of April, as formerly.

ACRL Headquarters will order preprints or extra proofs of the statistics if there is substantial demand for them. These preprints or proofs can probably be mailed out before January I, several weeks before the January issue. A charge (not more than a dollar) will be made for this service. If for budget planning or other reasons you are eager to secure a preprint as soon as possible, please send a note to that effect to the ACRL Executive Secretary, 5o E. Huron St., Chicago I I, Ill. 